\title{
Impact of Technological Pedagogical Content Knowledge Based Education Applications on Prospective Teachers' Self-Efficacy Belief Levels Toward Science Education
}

\author{
Onder Sensoy ${ }^{1}$, Halil Ibrahim Yildirim ${ }^{1}$ \\ ${ }^{1}$ Gazi Education Faculty, Department of Science Education, Gazi University, Ankara, Turkey \\ Correspondence: Onder Sensoy, Gazi Education Faculty, Department of Science Education, Gazi University, Ankara, \\ Turkey.
}

Received: July 10, $2018 \quad$ Accepted: July 30, $2018 \quad$ Online Published: August 1, 2018

doi:10.11114/jets.v6i10.3433 URL: https://doi.org/10.11114/jets.v6i10.3433

\begin{abstract}
The purpose of this study is to examine the impact of technological pedagogical content knowledge-based education applications on prospective teachers' self-efficacy belief levels toward science education. The study was conducted on the 3rd year prospective science teachers of a public university and continued for 14 weeks. In the study, quasi -experimental method, pretest-posttest experimental design with a control group. The research was performed in the Instructional Technologies and Material Design courses during the education year of 2015-2016. In the research, one of the classes of the 3rd years was determined as a control and another one as an experimental group. There were 65 students (control=33, experiment=32) in the study group. As the instrument of data collection, the self-efficacy belief levels toward science education scale was used and the scale was applied as pretest, posttest and follow-up test. Cronbach Alpha $(\alpha)$ consistency coefficient of the scale is 0.82. To the students in the experimental group, the education applications based on Technological Pedagogical Content Knowledge were introduced by the researcher; the courses were made with these applications and they were requested to use these applications that they learned in the materials that they were making. As for the control group, the courses were made with the current curriculum. The research results show that the self-efficacy belief levels of prospective science teachers toward science education design is higher in the experimental group than the students in the control group.
\end{abstract}

Keywords: technology, self-efficacy belief, material project, science teaching

\section{Introduction}

Today, it is compulsory and necessary to follow up the scientific and technological developments in many fields. One of the most important ones of these fields is education and training fields. In the contemporary studies, made in the field of training, the sufficiency of teachers' use of instructional technologies and integrating them into the education process became a current necessity with the developing technologies. The necessity of bringing the information and communication technology to the education and training environment, of using them in these environments in accordance with a high-quality understanding of education, and of popularizing this usage is known. In many of the conducted studies, it was concluded that the application of technology in education increases students' success (Wainwright, 1989; Gonen, Kocakaya \& Inan, 2006; Tuysuz, 2010; Pektas, Turkmen \& Solak, 2006; Bozkurt \& Sarikoc, 2008; Turkan, Yalcin \& Turkan, 2010; Tas, Kose \& Cepni, 2006). Taking this situation into consideration, it also became an inevitable necessity that educators need to have qualifications in technological knowledge. Therefore, technological knowledge was integrated into the knowledge types that the teachers must have and Technological Pedagogical Content Knowledge (TPACK) emerged (Koehler \& Mishra, 2005).

In order for TPACK to be understood, pedagogical domain knowledge (PCK) must first be understood. According to Shulman (1986), PCK is the knowledge that allow the use of analogies, examples, explanations, presentations and presentation methods that represent the concepts in the top manner so as to allow the subject to be understood. With this feature, PCK is a kind of information that distinguishes teachers from the experts on the subject content. Recently, the TPACK sufficiency has been also added by including the technological aspect in the PCK sufficiency that the teachers need to have. According to the definition of Mishra \& Koehler (2009), TPACK is a sufficiency of teacher, consisted of the intersection of pedagogy, content and technology. TPACK is the fundamental of teaching with technology. In other words, 
TPACK is an important kind of information that passed beyond three components (subject content, technology, pedagogy) and that is different from the content knowledge that an expert of a discipline and technological knowledge that a technology expert can have and the general pedagogical information that a teacher can have (Mishra \& Koehler, 2006).

When the conducted studies and projects examined, it is seen that a large budget is spared for the use of technology in training and a great effort is spent in this matter. However, even if our schools have a sufficient technologic equipment, those are the teachers who will materialize the instructional technologies in the education programs (TED, 2009). Also, within the scope of the education program of the life sciences, the teachers are expected to provide the technology integration into the education-learning process, considering their current technological developments (MEB, 2013; Harris \& Hofer, 2011).

The computer courses that are included in the teacher training programs in the international literature allow the prospective teachers to learn the technical skills on the usage of computers in their classrooms, but it was later understood that these technical skills do not turn into education skills inside classrooms (Lambert \& Gong, 2010). In our era, which we define as the technology era, it is expected from the teachers of sciences and technology to be technology literate individuals. However, it is known that the prerequisite for teachers to educate technology literate individuals is their being technology literate and to use technological and pedagogical knowledge that they had by merging together and using in the in-class applications effectively and efficiently (Koehler \& Mishra, 2008; Angeli \& Valanides, 2009; Niess, 2008; Mishra \& Koehler, 2006). These technological skills are necessary for the prospective teachers. Integrating technology with education, nonetheless, is not as much easy as learning technological skills. (Koehler \& Mishra, 2008).

Allowing the teachers' TPACK levels to increase, in other words allowing them to have knowledge about teaching their own contents with information and communication technologies, is important in terms of allowing their students to grow up as literate individuals in terms of science and technology. Furthermore, the teachers' self-efficacy is one of the variables that affect their achievement and goals in their professional lives (Cakıroglu, Cakıroglu \& Boone, 2005). The belief of the individuals in their capacities of organizing and realizing a group of activities that are necessary to display a certain performance is defined to be self-efficacy. Therefore, self-efficacy has an impact on the choices that they will make. The teachers that have high self-efficacy levels are more eager and decisive, when they confront a problem in their professional lives (Bandura, 1977). The teachers who have low self-efficacy levels face difficulties in establishing an effective learning-teaching environment and give confidence to their students in the process of education (Tschannen- Moran \& Woolfolk Hoy, 2007). Self-confidence, however, is accepted to be one of the criteria of the concept of self-efficacy (Shell et al., 1989). Their self-confidence levels play an significant part in the teachers' being able to successfully integrate their technology in the education process and thus organizing their own learning-teaching environments (Bitner \& Bitner, 2002; Ertmer, Ottenbreit-Leftwich, 2010; Abbitt, 2011; Wang, Ertmer \& Newby, 2004; Sahin, Akturk \& Schmidt, 2009).

When the literature is pass in review, it is probable to come across with works about the determination of the teachers' TPACK levels (Jang \& Tsai, 2013; Jordan, 2011; Archambault \& Crippen, 2009; Avci, 2014; Bilici \& Guler 2016; Karadeniz \& Vatanartiran, 2015; Karakaya, 2013; Karatas, 2014; Mutluoglu, 2012; Timur \& Imer-Cetin, 2014; Ozbek 2014; Sad at al., 2015) or examining the development of the prospective teachers' TPACK levels (Niess, 2005; Akkaya, 2009; Timur, 2011; Canbazoglu-Bilici, 2012). There are also studies that examine TPACK in terms of the teachers' perception of self-confidence (Savas et al., 2010; Kaya et al., 2010; Sarikaya et al., 2012; Sancar-Tokmak et al., 2013). However, the self-efficacy studies about how much the teachers can reflect their TPACK knowledge on their educations are also needed.

Many new teachers graduate with limited knowledge about the strategies on integrating technology to their routine educations (Suharwoto, 2006). By this reason, the graduation of the prospective teachers as individuals that are sufficient in terms of the education applications, based on the TPACK, and in peace with technology as well as having confidence in themselves regarding to their fields, will also make it easier to achieve the education goals by making the education-training system more efficient.

\subsection{Purpose of the Research}

The purpose of this research is to examine the impact of the change that TPACK-based education applications make on prospective teachers' self-efficacy belief levels toward science education.

\section{Method}

\subsection{Research Design}

The research was developed by using a quasi-experimental method. The experimental pattern with pretest-posttest control is applied in the research (Linn \& Gronlund, 2000). As ready-made classes are used as control and experimental groups, and no replacement was made between the students that are in these classes, and the principles of randomness 
or assigning students to experiment and control groups by drawing tickets were not made, the research model is quasi-experimental in the study (Karasar, 2016; Buyukozturk at al., 2016).

\subsection{Study Group}

The study group of the research was constituted by the prospective students of the 3rd year of the Department of Science Teaching of the Faculty of Education in the education year of 2015-2016. In the determination of the sampling in the research, the convenience sampling method was used (Buyukozturk at al., 2016; Karasar, 2016).

In terms of the selection of experimental and control groups, the branches were matched-up according to the equivalency at first. In this pairing, the average grades of the classes in the previous term were taken as the basis. In the pairing, accordingly made, $\mathrm{B}$ and $\mathrm{C}$ classes among $\mathrm{A}, \mathrm{B}$ and $\mathrm{C}$ classes were decided to be equal to each other and these two classes were used in the study. The decision of determining which group is to be the experimental and control group was made with the random assignment method. All of the prospective teachers that constitute the groups are 65 students who came from general high schools or Anatolian high schools, both of which are state schools.

Table 1. Profile information about the research groups

\begin{tabular}{lccccc}
\hline & & \multicolumn{2}{c}{ Control } & \multicolumn{2}{c}{ Experimental } \\
\cline { 2 - 6 } Sex & & $\%$ & $\mathrm{f}$ & $\%$ & $\mathrm{f}$ \\
\hline \multirow{3}{*}{ Female } & 78.8 & 26 & 74.4 & 27 \\
\cline { 2 - 6 } & Male & 21.2 & 7 & 15.6 & 5 \\
\cline { 2 - 6 } & $0.00-0.99$ & 0 & 0 & 0 & 0 \\
\cline { 2 - 6 } & $1.00-1.99$ & 12.1 & 4 & 6.2 & 2 \\
\cline { 2 - 6 } & $2.00-2.99$ & 69.7 & 23 & 84.4 & 27 \\
\cline { 2 - 6 } Computer Use Time Point Average & $3.00-4.00$ & 18.2 & 6 & 9.4 & 3 \\
\cline { 2 - 6 } & Less than 1 hour day & 15.2 & 5 & 12.5 & 4 \\
\cline { 2 - 6 } & 4 hours and more on the day & 12.1 & 4 & 18.7 & 6 \\
\hline \multirow{2}{*}{ Total } & & 50.78 & 33 & 49.2 & 32 \\
\hline
\end{tabular}

\subsection{Data Collection Instrument}

Data of the research were collected with "Scale for Determining Self-Efficacy Belief Levels" for determine the Self Efficacy Belief levels toward the science education of the prospective teachers. The total point, taken from the test, displays the self-efficacy belief level of the individual.

The scale used by Kaptan and Korkmaz (2001) was used to determine the self-efficacy beliefs of science teacher candidates regarding science teaching. One year before the experimental process, the scale was applied to 150 different prospective science teachers, who are at the same year of education. As the result of this application the Cronbach Alpha $(\alpha)$ convenience coefficient of the scale was calculated to be 0.82 . The scale is consisted of 30 items, in which the five-point Likert evaluation scale from "I Certainly Agree" to "I Certainly Disagree". 3 months after the scale was applied as pretest and posttest to both the control and the experimental group, it was applied again as the follow-up test to the students in the control and experiment groups.

\subsection{Process Steps}

The research was made in the Instructional Technologies and Material Design courses in the 1st term of the education year of 2015-2016. These courses, compulsorily given in the programs that train science teachers in the education faculties, are conducted as 2 hours of application and 2 hours of theory, to be 4 hours in total. During the research, the courses, convenient for the current education program for the control group, were studied and materials, related to science education, were requested in the application part of the lesson. To the persons in the experimental group, the education applications based on TPACK were introduced by the researcher; the courses were studied with these applications and the persons were requested to use these applications in the materials that they were making. These applications are consisted of mobile applications, simulation, online assessment and evaluation instruments, effective presentation programs, animation, virtual laboratory environments, augmented reality applications, social media tools and field-specific technological instruments. The lessons were given by the same academic member for 14 weeks in both groups. A pretest was applied to experimental and control groups at the beginning of the research. 


\subsection{Data Analysis}

In the determination of the dispersions of the answers that were given by the students as well as in researching whether the dispersion of the quantitative data, gathered with the data collection instruments, are normal the central dispersion statistics, such as central tendency and coefficient of skewness like mode, median and mean, and the dispersion statistics, such as standard deviation and coefficient of kurtosis. Before the points, gathered by the data collection instruments, were analyzed, which statistical method was going to be used in the analysis of the quantitative data, gathered by the assessment instruments, was decided by conducting a research. During the analysis of the data, gathered in the quantitative researches, non-parametric (not parametric) and parametric statistical methods can be used. To be able to use the parametric statistical analysis methods in the study, the quantitative data, gathered by the assessment instruments, have to have a normal dispersion (Sim \& Wright, 2002). In this matter, the analyses were made in order to determine the statistical method, to be used in the analysis of the data, and their results are given below. Based on the findings in table 1, it was examined whether the students' points displayed a normal distribution or not.

Table 2. Descriptive statistical results of pretest, posttest and follow-up test points of students in control and experiment groups

\begin{tabular}{lllccccccc}
\hline Test & Grup & $\mathrm{N}$ & $\overline{\mathrm{X}}$ & $\mathrm{S}$ & Median & Mode & Kurtosis & Skewness & Shapiro-Wilk \\
\hline \multirow{2}{*}{ Pretest } & Control & 33 & 110.15 & 13.05 & 108.00 & 102.00 & -.126 & .671 & .334 \\
& Experiment & 32 & 111.81 & 10.66 & 111.50 & 119.00 & .201 & .476 & .664 \\
\hline \multirow{2}{*}{ Posttest } & Control & 33 & 112.27 & 12.68 & 114.00 & 114.00 & -.703 & 1.046 & .194 \\
& Experiment & 32 & 121.72 & 11.34 & 122.00 & 115.00 & -.282 & .985 & .780 \\
\hline \multirow{2}{*}{ Follow-up Test } & Control & 33 & 110.45 & 9.08 & 111.00 & 102.00 & -.087 & -.495 & .935 \\
& Experiment & 32 & 119.09 & 9.32 & 119.50 & 118.00 & -185 & .273 & .680 \\
\hline
\end{tabular}

It is seen that the means of the students points, median and mode values are close to one another. Besides, it is seen that the kurtosis and skewness values of the points that the students took from this scale was between the range of -1.5 and +1.5 . The closeness among the arithmetic mean, median and mode values of the students in this scale and the findings about the range (range: between -1.5 and +1.5 ) of coefficients of kurtosis and skewness display that the gathered data are dispersed in a normal manner (Koklu, Buyukozturk \& Bokeoglu, 2006; Kalayci, 2008; Tabachnick \& Fidell, 2013). It was decided that the usage of the parametric tests was convenient in the analysis of the data, which were found to display a normal distribution on the basis of these descriptive statistical results. Considering the data of the pre-test, post-test and follow-up test of the control and experimental groups has a significance level higher than .05 according to the Shapiro-Wilk significance level analysis, it can be said that the data were dispersed normally. In this matter, in order to find whether there is a significant difference between the points of the self-efficacy, pretest, posttest and follow-up test, "Independent Samples t-Test" was applied and Single Factor ANOVA for the repeated measures in order to compare the self-efficacy pretest, posttest and follow-up test points of the students both in the control and experiment groups. The results were evaluated at the significance level of .05 .

\section{Findings}

In this part, the necessary analyses were made by comparing the data, gathered from the students in the control group, in which the lessons were made with the methods and techniques recommended by the current curriculum and in the experimental group, in which the educational applications based on the TPACK.

Table 3. The results of the independent samples t-test of the pretest points about the self-efficacy belief of the students in the control and experiment groups toward the science education

\begin{tabular}{lcccccc}
\hline Group & $\mathrm{N}$ & $\overline{\mathrm{X}}$ & $\mathrm{S}$ & $\mathrm{df}$ & $\mathrm{t}$ & $\mathrm{p}$ \\
\hline Control Group & 33 & 110.15 & 13.05 & 63 & .561 & .577 \\
Experimental Group & 32 & 111.81 & 10.66 & & & \\
\hline
\end{tabular}

There is not any significant difference between the self-efficacy points of the persons in the sampling group before the research. $(\mathrm{t}(63)=.561 ; \mathrm{p}>.05)$. According to these data, as the self-efficacy belief levels of the persons, who will take the Instructional Technologies and Material Design lesson, toward science education before the conducted experimental research, were found to be $X=111.81$ in the experimental group and $X=110.15$ in the control group, they show similarities. Accordingly, the absence of any difference at a significant level between the self-efficacy belief levels of the persons complies with the purpose of the study and displays that the groups are on equality.

Table 4. The results of the independent samples t-test of the posttest points about the self-efficacy belief of the students in the control and experiment groups toward the science education

\begin{tabular}{lcccccc}
\hline \multicolumn{1}{c}{ Group } & $\mathrm{N}$ & $\mathrm{X}$ & $\mathrm{S}$ & $\mathrm{df}$ & $\mathrm{t}$ & $\mathrm{p}^{*}$ \\
\hline Control Group & 33 & 112.27 & 12.68 & 63 & 3.162 & .002 \\
Experimental Group & 32 & 121.72 & 11.34 & & & \\
\hline
\end{tabular}


When the Table 4 is examined, there is a significant difference between the self-efficacy belief level points between the students of the control and experimental groups after the research and this difference is in favor of the experimental group $(\mathrm{t}(63)=3.162 ; \mathrm{p}<.05)$ the means of the self-efficacy belief levels are $\mathrm{X}=121.72$ in the experimental group and $\mathrm{X}$ $=112.27$ in the control group after the experimental research. Based on the result that there is a difference at a significant level between the students of the control and experimental groups' self-efficacy belief levels toward science education in favor of the experimental group, it can be said that the instructional applications, based on the TPACK, have a positive contribution on the self-efficacy levels of the prospective teachers toward science education.

Table 5. The results of the independent samples t-test of the follow-up test points about the self-efficacy belief of the students in the control and experiment groups toward the science education

\begin{tabular}{lcccccc}
\hline \multicolumn{1}{c}{ Group } & $\mathrm{N}$ & $\overline{\mathrm{X}}$ & $\mathrm{S}$ & $\mathrm{df}$ & $\mathrm{t}$ & $\mathrm{p}^{*}$ \\
\hline Control Group & 33 & 110.45 & 9.08 & 63 & 3.784 & .000 \\
Experimental Group & 32 & 119.09 & 9.32 & & & \\
\hline
\end{tabular}

$* \mathrm{p}<.05$

When the data in the Table 5 are examined, it is seen that there is a significant difference between the self-efficacy belief levels between the prospective teachers of the control and experimental groups toward the science education, three months after the research was completed and this difference is in favor of the experimental group $(\mathrm{t}(63)=3.784$; $\mathrm{p}<.05)$. Therefore, the self-efficacy levels of the students in the experimental group was higher than the students in the control group at a significant level, three months after the research was completed.

Accordingly, it can be said that the TPACK applications are more effective than the education applied in the control group in terms of providing the conservation of the development in the prospective teachers' points of self-efficacy belief toward the education of science. In other words, this finding presents that the impact of the experimental action still continues.

Table 6. Measures of central tendency and dispersion of the self-efficacy belief points toward the education of science in the pretest, posttest and follow-up test of the students in the control group

\begin{tabular}{lllll}
\hline Measurement No & Measurement & $\mathrm{N}$ & $\overline{\mathrm{X}}$ & $\mathrm{S}$ \\
\hline 1 & Pretest & 33 & 110.15 & 13.05 \\
2 & Posttest & 33 & 112.27 & 12.68 \\
3 & Follow-up Test & 33 & 110.45 & 9.08 \\
\hline
\end{tabular}

Table 7. The results of the single factor ANOVA of repeated measures for the self-efficacy belief points toward the education of science in the pretest, posttest and follow-up test of the students in the control group

\begin{tabular}{lcccccl}
\hline Source of the Variance & Sum of Squares & df & Mean of Squares & F & p & Significant Difference \\
\hline Between subjects & 8705.838 & 32 & 272.057 & & & - \\
Measurement & 86.869 & 2 & 43.434 & .613 & .508 & \\
Error & 4535.131 & 64 & 70.861 & & & \\
Total & 13327.838 & 98 & & & &
\end{tabular}

According to Table 7, it was found that the prospective science teachers within the control group had their self-efficacy belief pretest $(X=110.15)$ posttest $(X=112.27)$ and follow-up test $(X=110.45)$. When the Table 7 was analyzed, it is seen that the difference between the pretest, posttest, pretest, follow-up test and posttest follow-up test points were not significant $(\mathrm{F}(2-64)=.613 ; \mathrm{p}>.05)$. In that case it can be assessed that the education method followed in the courses of the control group does not cause a change in the self-efficacy belief levels of the prospective science teachers.

Table 8. Measures of central tendency and dispersion of the students within the experimental group in regard to pretest, posttest and follow-up test in their self-efficacy beliefs towards science education

\begin{tabular}{lllll}
\hline Measurement No & Measurement & $\mathrm{N}$ & $\overline{\mathrm{X}}$ & $\mathrm{S}$ \\
\hline 1 & Pretest & 32 & 111.813 & 10.657 \\
2 & Posttest & 32 & 121.719 & 11.340 \\
3 & Follow-up Test & 32 & 119.094 & 9.323 \\
\hline
\end{tabular}


Table 9. Single factor ANOVA results of the students within the experimental group for the repeated measures of their pretest, posttest and follow-up test in their self-efficacy beliefs towards science education

\begin{tabular}{lcccccc}
\hline Source of the Variance & Sum of Squares & df & Mean of Squares & F & p & Significant Difference \\
\hline Between subjects & 6205.833 & 31 & 200.188 & & & \\
Measurement & 1685.771 & 2 & 842.885 & 13.077 & .000 & $1-2$ \\
Error & 3996.229 & 62 & 64.455 & & & $1-3$ \\
Total & 11887.833 & 95 & & & & \\
\hline
\end{tabular}

$* \mathrm{p}<.05$

According to Table 8 , the posttest point mean $(X=121.719)$ and measurement of change mean $(X=119.094)$ of the students within the experimental group in regard to their self-efficacy levels is higher than their pretest point mean $(\mathrm{X}=111.813)$. When Table 9 was analyzed, it is seen that the difference of the points between pretest, posttest; pretest and measurement of change were significant $\left(\mathrm{F}_{(2-62)}=13.077 ; \mathrm{p}<.05\right)$. It is observed that there is no significant difference between post-test and measurement of change. This can be explained through the fact that the mean between the posttest and measurement of change did not change much and the information became more persistent.

\section{Discussion and Conclusion}

At the end of the study it was seen that during the Instructional Technologies and Material Design course the instructional applications based on TPACK were shown and that the self-efficacy belief levels of the experimental group students towards science education provided in this manner increased significantly. There was no change in the self efficacy belief levels of the students towards the science education, which was provided through methods and applications within the current curriculum of the Instructional Technologies and Material Design courses. At the same time, it was reached to the conclusion that the self efficacy belief levels of the prospective teachers towards science education were unchanged during the courses where the instructional applications based on TPACK were given. Many studies, which complement this current study, analyzed the self-efficacy perceptions of the teachers towards sciences with the basis of technological pedagogical content knowledge, and reached similar results (Abbitt, 2011; Kaya at al., 2011; Lee \& Tsai, 2010).

Graham et al. (2009), provided training throughout an eight-month program that consisted of three stages (learning, enacting and transfer) for 15 science teachers with different professional experiences). Through the survey improved by the researchers before and after the program, the self-efficacy levels of the teachers towards their knowledge on TPACK, TPK, TCK and TK were analyzed. As a result of the independent t-test and coding, it was found that the self-efficacy of the teachers towards the knowledge analyzed in this study improved. In the beginning of the work, it was found that the self-efficacy of the teachers towards TK was the highest. Tasar and Timur (2010), analyzed the improvement of the prospective science teachers in TPACK through the research method of mixed methods. In the study, the teachers executed microteaching through interactive physics animations based on research-questioning within the scope of the topic of force and motion. The improvements of the prospective teachers were tracked throughout the microteaching sessions. The scale developed by Graham et al. (2009) so as to determine the TPACK self-efficacy levels and improvements of the participants was translated into our language. Qualitative data of the study were collected through observation, interview, lesson plans and microteaching feedback forms. It was found that among the knowledge on TK, TCK, TPK and TPACK, the TK self-efficacy levels of the prospective teachers were found to be highest, while their TCK levels were found to be the lowest. Similarly, the findings acquired via qualitative data instruments supported that the TCK levels of the persons were low. It was suggested that the knowledge types of BK, TCK, TPK and TPACK were co-related and these knowledge types should be analyzed together. Canbazoglu (2012), conducted a study with mixed methods on the prospective science teachers. Krajcik and Borko (1999)'s pedagogical content knowledge (PCK) model was adapted to TPACK and used in the study. In the beginning of the fall term of the study, 27 prospective teachers participated in a five-week training structure in accordance with the TPACK model's components, and later on these prospective teachers prepared lesson plans enriched with technology in different science topics for eight week and conducted microteaching. When the self-efficacy levels of the prospective science teachers towards TPACK were analyzed, it was determined that the self-efficacy levels of 27 prospective science teachers increased at the end of the 1 st semester in comparison to the beginning of the 1st semester.

As can be seen, the self-efficacy beliefs of the teachers towards TPACK play an significant role in the usage of technology (Lee and Tsai, 2010). Efficacy perceptions of the teachers or prospective teachers and their self-confidence levels are effective in the usage of technology in education and in increasing the quality of the lessons. (Gomleksiz \& Fidan, 2011; Lee \& Tsai, 2010; Akgun, 2013; Christanse, 2002) However, the information technologies were not simply added into the lessons, they must be fully integrated to the education process (Gorghiu \& Gorghiu, 2010). Science and technology teachers must effectively integrate technological knowledge into their training. Therefore, their TPACK must be good. Cakir \& Yildirim in a study they conducted in 2009 emphasized the difficulties of integrating technology 
into schools. Views of in-service and pre-service computer teachers showed that there are many factors such having limited internet access, excessive class size and insufficient knowledge of teachers in using technology successfully during their teaching existed. In addition, it was stated in other studies (Cure \& Ozdener, 2008; Usluel, Mumcu \& Demirarslan, 2007) that the lack of technology in classes and teachers' lack of knowledge in using these technologies effectively in class were the most important obstacles. Other researchers showed that pre-service Science, Mathematics, History, Turkish, Preschool and Elementary School teachers felt insufficient in using computers and internet as teaching tools (Erdemir, Bakirci \& Eyduran, 2009).

Using technology in a class is a problem that is complex and contains a lot of factors within. However, the prospective teachers are expected to teach by integrating technology, pedagogy along with their fields. Therefore, instead of focusing on the basic computer skills for the courses related to the instructional technology that is part of the teacher trainee programs; successful integration of the technology into education by the prospective teachers must be reviewed again (Lambert, Gong \& Cuper, 2009). These courses will be more elaborate since they will cover the pedagogical concepts, content and program knowledge as well as teaching with technology (Lambert \& Gong, 2010).

In parallel with all of this information, it is recommended to suplly opportunities to the prospective teachers at the universities in which they can make the technological applications in a real classroom environment in order to gain teaching experience and to give place to the contemporary TPACK-Based Instructional Applications and to the effective technology usage within the scope of the related lessons. In accordance with the information, gathered at the university in this manner, it will be provided that the future teachers will be trained as the individuals who can apply technology in their classes and thus feel themselves more effective in the transfer of the subjects of science to the student.

\section{References}

Abbitt, J. (2011). An investigation of the relationship between self-efficacy beliefs about technology integration and technological pedagogical content knowledge (TPACK) among preservice teachers. Journal of Digital Learning in Teacher Education, 24(4), 134-143. https://doi.org/10.1080/21532974.2011.10784670

Akgun, F. (2013). Preservice teachers' web pedagogical content knowledge and relationship between teachers' perceptions of self efficacy. Trakya University Journal of Education, 3(1), 48-58.

Akkaya, E. (2009). Investigating technological pedagogical content knowledge for derivative concept: Knowledge of Student Difficulties. Unpublished Master Thesis. Marmara University, Istanbul.

Angeli, C., \& Valanides, N. (2009). Epistemological and methodological issues for the conceptualization, development, and assessment of ICT-TPCK: Advances in technological pedagogical content knowledge (TPCK). Computers \& Education, 52, 154-168. https://doi.org/10.1016/j.compedu.2008.07.006

Archambault, L., \& Crippen, K. (2009). Examining tpack among K-12 online distance educators in the United States. Contemporary Issues in Technology and Teacher Education, 9(1), 71-88.

Avc1, T. (2014). Determining technological pedagogic content knowledge and self-confidence levels of science teachers. Unpublished Master Thesis. Celal Bayar University. Manisa

Bandura, A. (1977). Social learning theory. New York: General Learning Press.

Bilici, S., \& Guler, C. (2016). Investigation of teachers' tpack levels with respect to use of instructional technologies. Elementary Education Online, 15(3), 898-921.

Bitner, N., \& Bitner, J. (2002). Integrating technology into the classroom: Eight keys to success. Journal of Technology and Teacher Education, 10(1), 95-100.

Bozkurt, O., \& Kaya, O. N. (2008). Teaching about ozone layer depletion in Turkey: pedagogical content knowledge of science teachers. Public Understanding of Science, 17, 261-276. https://doi.org/10.1177/0963662506071787

Buyukozturk, S., Cakmak-Kilic, E., Akgun, O. E., Karadeniz, S., \& Demirel, F. (2016). Bilimsel arastirma yontemleri. Ankara: Pegem Academy.

Cakiroglu, J., Cakiroglu, E., \& Boone, W. J. (2005). Pre-service teacher self-efficacy beliefs regarding science teaching: A comparison of pre-service teachers in Turkey and the USA. Science Educator, 14, 31-40.

Canbazoglu, B. S. (2012) The pre-service science teachers? technological pedagogical content knowledge and their self-efficacy. Unpublished Doctoral Thesis, Gazi University. Ankara, Turkey.

Christanse, R. (2002). Effects of technology integration education on the attitudes of teachers and students. Journal of Research on Technology in Education, 34(4) 411-433. https://doi.org/10.1080/15391523.2002.10782359 
Cure, F., \& Ozdener, N. (2008). Teachers' information and communication technologies (ict) using achievements and attitudes towards ict. Hacettepe University Journal of Education, 34, 41-53.

Erdemir, N., Bakirci, H., \& Eyduran, E. (2009) Teacher Candidates' Ability to Use Technology in Education Detection of Self-confidence. Journal of Turkish Science Education, 6(3), 99-108.

Ertmer, P. A., \& Ottenbreit-Leftwich, A. T. (2010). Teacher technology change: How knowledge, confidence, beliefs, and culture intersect. Journal of Research on Technology in Education, 42(3), 255-284. https://doi.org/10.1080/15391523.2010.10782551

Gomleksiz, M. N., \& Fidan, E. K. (2011). Self-Efficacy perception levels of prospetive teachers enrolled at pedagogical formation course toward web pedagogical content knowledge. International Periodical for the Languages. Literature and History of Turkish or Turkic., 6(4), 593-620.

Gonen, S., Kocakaya, S., \& Inan, C. (2006). The effect of the computer assisted teaching and 7E model of the constructivist learning methods on the achievements and attitudes of high school students. The Turkish Online Journal of Educational Technology - TOJET, 5(4), ISSN: 1303-6521.

Gorghiu, L. M., \& Gorghiu, G. (2010). ICT tools and their effectiveness in science lessons-the FISTE project experience. In I. Ellis \& B. Ralle (Eds.), Strategies and Assessment, Germany: Shaker Verlag. ss. 259-266.

Graham, C. R., Burgoyne, N., Cantrell, P., Smith, L., St. Clair, L., \& Harris, R. (2009). TPACK development in science teaching: Measuring the TPACK confidence of inservice science teachers. TechTrends, 53(5), 70-79. https://doi.org/10.1007/s11528-009-0328-0

Harris, J. B., \& Hofer, M. J. (2011). Technological pedagogical content knowledge (TPACK) in action: A descriptive study of secondary teachers' curriculumbased, technology-related instructional planning. Journal of Research on Technology in Education, 43(3), 211-229. https://doi.org/10.1080/15391523.2011.10782570

Hoy, A. W., \& Spero, R. B. (2005). Changes in teacher efficacy during the early years of teaching a comparison of four measures. Teaching and Teacher Education, 21(4), 343-356. https://doi.org/10.1016/j.tate.2005.01.007

Jang, S. Y., \& Tsai, M. F. (2013). Exploring the tpack of Taiwanese secondary school science teachers using a new contextualized tpack model. Australasian Journal of Educational Technology, 29(4), 566-580. https://doi.org/10.14742/ajet.282

Jordan, K. (2011). Beginning teacher knowledge: Results from a self-assessed tpack survey. Australian Educational Computing, 26(1), 16-26.

Kalayci, S. (2008). Spss uygulamali cok degiskenli istatistik teknikleri. Ankara: Asil publishing.

Kaptan, F., \& Korkmaz, H. (2001). Coklu Zeka Kurami Tabani Fen Ogretiminin Ogrenci Basarisina ve Tutumuna Etkisi, IV. National Science and Mathematics Education Congress,. 2000, Milli Egitim Publishing, Ankara

Karadeniz, S., \& Vatanartiran, S. (2015). Primary school teachers' technological pedagogical content knowledge. Elementary Education Online, 14(3), 1018-1028.

Karakaya, C. (2013). Technological pedagogical content knowledge (TPCK) of chemistry teachers who work in pilot high schools in Fatih Project. Unpublished Master Thesis, Gazi University. Ankara, Turkey.

Karasar. N. (2016) Bilimsel arastirma yontemi (30th edition). Nobel Academic Publishing.

Karatas, A. (2014). Investigation high school teachers' pedogogical content knowledge competence in implementing the Fatih Project: Example of Adiyaman province. Unpublished Master Thesis, Sakarya University. Sakarya, Turkey.

Kaya, Z., Emre, I., \& Kaya, O. N. (2010). Sinif ogretmeni adaylarinin teknolojik pedagojik alan bilgisi (tpab) acisindan oz guven seviyelerinin belirlenmesi. 9 th Class Teacher Training Symposium, Elazig, 643-651.

Kaya, Z., Ozdemir, T. Y., Emre, G., \& Kaya, O. N. (2011). Bilisim teknolojileri ogretmen adaylarinin teknolojik pedagojik alan bilgisi oz yeterlilik seviyelerinin belirlenmesi. International Computer \& Instructional Technologies Symposium, Firat University, Elazig.

Koehler, M. J., \& Mishra, P. (2008). Introducing Technological Pedagogical Knowledge. In AACTE (Eds.). The Handbook of Technological Pedagogical Content Knowledge for Educators (p.3-30). New York: Routledge.

Koehler, M. J., \& Mishra, P. (2009). What is technological pedagogical content knowledge? Contemporary Issues in Technology and Teacher Education, 9(1), 60-70. https://doi.org/10.1080/07380560903536272

Koklu, N., Buyukozturk, S., \& Bokeoglu, C. O. (2006). Sosyal bilimler icin istatistik. Ankara: Pegem Academic Publishing. 
Lambert, J., \& Gong, Y. (2010). 21st century paradigms for pre-service teacher technology preparation. Computers in the Schools, 2l(1), 54-70.

Lambert, J., Gong, Y., \& Cuper, P. (2009). Technology, transfer, and teaching: the impact of a single technology course on preservice teachers' computer attitudes and ability. Journal of Technology and Teacher Education, 16(4), 385-410.

Lee, M. H., \& Tsai, C. C. (2010). Exploring teachers' perceived self-efficacy and technological pedagogical content knowledge with respect to educational use of the World Wide Web. Instructional Science, 38(1), 1-21. https://doi.org/10.1007/s11251-008-9075-4

Linn, M. C., \& Hsi, S. (2000). Computers, teachers, peers science learning partners. London: Mahwah, NJ: Lawrence Erlbaum Associates.

Magnusson, S., Krajcik, J., \& Borko, H. (1999). Nature, Sources, and Development of Pedagogical Content Knowledge for Science Teaching. In J. Gess-Newsome \& N. Lederman (Eds.), Examining Pedagogical Content Knowledge: The Construct and Its Implications for Science Education (pp. 95-132).

Milli Egitim Bakanligi (MEB) (2013). Ilkogetim kurumlari (Ilkokullar ve ortaokullar) fen bilimleri dersi (3, 4, 5, 6, 7 ve 8. Siniflar) Ogretim Programi. Retrieved July 27, 2013 from http://mebk12.meb.gov.tr/meb_iys_dosyalar/46/10/727140/icerikler/guncellenen-ogretim-programlari_788959.htm 1

Mishra, P., \& Koehler, M. J. (2006). Technological pedagogical content knowledge: a framework for teacher knowledge. Teachers College Record, 108(6), 1017-1054. https://doi.org/10.1111/j.1467-9620.2006.00684.x

Mutluoglu, A. (2012) Examining primary mathematics teachers' technological pedagogical content knowledge according to their preffered teaching styles. Unpublished Master Thesis, Necmettin Erbakan University. Konya, Turkey.

Niess, M. L. (2005). Preparing teachers to teach science and mathematics with technology: developing a technology pedagogical content knowledge. Teaching and Teacher Education, 21, 509-523. https://doi.org/10.1016/j.tate.2005.03.006

Niess, M. L. (2008). Guiding pre-service teachers in developing TPCK, In. AACTE Committee on Innovation and Technology (Eds.), Handbook Of Technological Pedagogical Content Knowledge (TPCK) For Educators (pp. 3-29). New York and London: Routledge.

Ozbek, A. (2014). The research of teachers' innovativeness level effect on TPACK competences. Unpublished Master Thesis, Necmettin Erbakan University. Konya, Turkey.

Pektas, M., Turkmen, L., \& Solak, K. (2006) The Effect of Computer Assisted Instruction in the Learning of Urinary System and Digestive System Units for the Science Teacher Candidates. Kastamonu Education Journal, 14(2), 465-472.

Sad, S. N., Acikgul, K., \& Delican, K. (2015). Senior Pre-service Teachers' Senses of Efficacy on their Technological Pedagogical Content Knowledge (TPACK). Journal of Theoretical Educational Science, 8(2), 204-235. https://doi.org/10.5578/keg.9480

Sahin, I., Akturk, A., \& Schmidt, D. (2009). Relationship of preservice teachers' technological pedagogical content knowledge with their vocational self-efficacy beliefs. In C. D. Maddux (Ed.), Research highlights in technology and teacher education 2009, (pp. 293-301). Chesapeake, VA: AACE.

Sancar, T. H., Yavuz, K. G., \& Yanpar-Yelken, T. (2013). An investigation of Mersin university early childhood pre-service teachers' self-confidence about their technological pedagogical content knowledge (TPACK). Ahi Evran University. Journal of Kirsehir Education Faculty, 14(1), 35-51.

Sarikaya, M., Kaya, V. H., Akdag, G., Ay, I., \& Dogan, A. (2012). Ogretmen adaylarinin teknolojik pedagojik alan bilgilerine iliskin oz guvenlerinin belirlenmesi. X National Science and Mathematics Education Congress. Nigde, s. 124.

Savas, M., Ozturk, N., \& Tuzun, Y. O. (2010). Fen bilgisi ogretmen adaylarinin fen egitiminde teknoloji kullanimi ile ilgili gorusleri ile iliskili olan faktorlerin belirlenmesi. IX National Science and Mathematics Education Congress, Izmir: Guler Publishing.

Shell, D. E., Murphy, C. C., \& Bruning, R. H. (1989). Self-efficacy and outcome expectancy mechanisms in reading and writing achievement. Journal of Educational Psychology, 81, 91-100. https://doi.org/10.1037/0022-0663.81.1.91 
Shulman, L. S. (1986). Those who understand; Knowledge growth in teaching. Educational Researcher, 15(2), 4-14. https://doi.org/10.3102/0013189X015002004

Sim, J., \& Wright, C. (2002). Research in health care: Concepts, designs and methods. United Kingdom, Cheltenham: Nelson Thornes Ltd.

Suharwoto, G. (2006). Secondary mathematics preservice teachers' development of technology pedagogical content knowledge in subject-specific, technology-integrated teacher preparation program. Phd thesis, Oregon State University.

Tabachnick, B. G., \& Fidell, L. S. (2013). Using multivariate statistics. (6th edition). Boston: Pearson.

Tas, E., Kose, S., \& Cepni, S. (2006). The Effects of Computer-Assisted Instruction Material on Understanding Photosynthesis Subject. International Journal of Environmental and Science Education, 1(2), 163- 171.

Tezcan, H., \& Yilmaz, U. (2003). Kimya ogretiminde kavramsal bilgisayar animasyonlari ile geleneksel anlatim yontemin basariya etkileri. Pamukkale University Journal of Education, 14(2), 18-32.

Timur, B. (2011). The development of pre-service science teachers? technological pedagogical content knowledge in force and movement subjects. Unpublished Doctoral Thesis, Gazi University. Ankara, Turkey.

Timur, B., \& Imer-Cetin, N. (2014). Fen ve teknoloji ogretmenlerinin teknolojik pedagojik alan bilgi duzeylerinin cesitli degiskenler acisindan incelenmesi.1st Eurasian Educational Research Congress, Istanbul University, İstanbul.

Tschannen-Moran, M., \& Woolfolk, H. A. (2007). The differential antecedents of self-efficacy beliefs of novice and experienced teachers. Teaching and Teacher Education, 23, 944-956. https://doi.org/10.1016/j.tate.2006.05.003

Turk Egitim Dernegi (TED). (2009). Ogretmen Yeterlikleri. Ankara: Adim Okan Matbaacilik Basim.

Turkan, S., Yalcin, N., \& Turkan, A. (2010). Elektrik unitesinin ogretilmesinde animasyonun ogrenci basarisina ve tutumuna etkisi. IX National Science and Mathematics Education Congress, Izmir: Guler Publishing.

Tuysuz, C. (2010). The effect of the virtual laboratory on students"e achievement and attitude in chemistry. International Online Journal of Educational Sciences, 2(1), 37-53.

Usluel, Y. K., Mumcu, K. F., \& Demiraslan, Y. (2007). ICT in the learning-teaching process: teachers' views on the integration and obstacles. Hacettepe University Journal of Education, 32, 164-178.

Wainwright, C. L. (1989). The effectiveness of a computer-assisted instruciton package in high school chemistry. Journal of Research in Science Teaching, 26(4), 275-290. https://doi.org/10.1002/tea.3660260402

Wang, L., Ertmer, P. A., \& Newby, T. J. (2004). Increasing preservice teachers' self-efficacy beliefs for technology integration. Journal of Research on Teaching in Education, 36(3), 231-250. https://doi.org/10.1080/15391523.2004.10782414

\section{Copyrights}

Copyright for this article is retained by the author(s), with first publication rights granted to the journal.

This is an open-access article distributed under the terms and conditions of the Creative Commons Attribution license which permits unrestricted use, distribution, and reproduction in any medium, provided the original work is properly cited. 